\title{
Resource-based view in strategic management of public organizations - a review of the literature'
}

M.A.Karolina Szymaniec-Mlicka University of Economics in Katowice Department of Public Management

\section{Introduction}

The growing importance of the public sector for socio-economic development of the country is reflected in the greater interest of researchers seeking answers about effective methods and tools for the management of public sector organizations. One of the important directions of research are issues of strategic management of the public organizations and searching for solutions improving their efficiency in that area, especially in an increasingly dynamic environment.

One of the proposed solutions is to use the resource-based view (in short: RBV) which focuses on the interior structure of the organization, as well as its resources and capabilities that will better meet the emerging challenges. This view has been widely used and appreciated in the management of private organizations. It lacks, however, the broader reference to literature in order to successfully implement it in the management of public organizations. This article presents

1 This article is part of a financial project funded by the National Science Centre, awarded on the basis of the decision no. DEC-2013/09/N/ HS /03657. 
an overview of research studies relating to the use of RBV in the management of public organizations.

\section{Resource-based view - solution to environmental turbulences}

Public organizations working as open systems operate in conjunction with the environment. Interaction between the organization and its environment occurs while it is assumed that the impact of the environment on organizations is much greater than vice versa. The theory and practice of management clearly indicate the need for a proper diagnosis of the environment as an essential element of building an organization's strategy, although the very concept of the environment and its components can be handled differently (SzymaniecMlicka 2014). Diagnosing the environment is a prerequisite for the successful building of the organizational strategy. However, it should be noted that in the face of increasing complexity and dynamics of the medical entities, this task has become more difficult and the conclusions drawn from the analysis are now less certain. The environment of public organizations tends to be turbulent, which results in their politicization and consequent inability to predict upcoming changes on one hand, and - on the other hand - their complexity stemming from the existence of a large number of stakeholders within public organizations, whose expectations they are forced to fulfill, and which often are mutually exclusive (Frączkiewicz-Wronka, Szymaniec 2014).

Literature in the field of management as one of the possible prescriptions for increasing environmental turbulence indicates the resource approach - ResourceBased View - which assumes that the success of the organization lies within the organization itself, or to be exact - in its valuable, intangible and not perfectly imitable resources (VRIO condition) allowing it to achieve a sustainable competitive advantage (Barney, Clark 2007). The development of this view is closely linked to the growing turbulence of environment, as in the context of its unpredictability, resources and competences are more stable base to generate strategies (Grant 2003).

This approach is particularly appreciated in the works of R. Krupski (2012, 2011) since it is the basis for building flexible strategies enabling a quick adaptation to dynamic changes in the environment and seeking the opportunity, which is a key competence in the face of increasing environmental turbulence. The work of M. Bratnicki and B. Ząbkowska (2007) points out the resources as being particularly important in an increasingly unpredictable environment, 
particularly emphasizing the role of knowledge management. A. Kozminski (2005) stresses the importance of resources in conditions of "generalized insecurity", that is the unpredictability of the external environment and internal organization. The organization should strive for potentialization (accumulation of potential, the ability to act in unpredictable situations) and also try to enable the provision of free resources, especially those that are intangible (Koźmiński 2005). Also in english literature, the resource approach appears as a response to the increasing dynamics of the environment:

- M.F. Waterhouse (1992): In a turbulent environment the manager (or leader) is not only a supervisor, a controller, but should also play the role of a gardener, that is - take care and develop the organization's resources, mainly human resources. In addition, strategic planning process in such environment should put more emphasis on stakeholder engagement, relationship with them;

- B. Dreyer, K. Grønhaug (2004): In conditions of uncertainty and turbulence of the environment, organizations should strive to increase their flexibility the ability to respond rapidly to emerging challenges within the environment. Thus, the flexibility of the organization can be seen as the strategic resource;

- E. Fredericks (2005): An organization's response to the increasing dynamics of the environment should result in an increased strategic flexibility of organization, which is based on the implementation of the resource approach, which focuses on the organization's resources in the way so it is able react quickly to changes and emerging opportunities;

- M.L. Pettus, Y.Y. Kor, J.T. Mahoney (2007): In a dynamically changing environment, organizations need to build strategic competencies, mainly strategic resource flexibility, allowing them to adapt to rapid change;

- S. Lev, A. Fiegenbaum, A. Shoham (2008): In a turbulent environment, the organization's most important resource is the knowledge and ability to be absorbed, while the ambient turbulence gives organization the opportunity to transform potential into real absorption capacity, simultaneously improving its overall performance;

- B.E. Perrott (2008): In a turbulent environment, it becomes necessary to develop skills of building strategies (including environmental analysis), which will allow for better management and adaptation to change.

As indicated earlier, the environment of public organizations is turbulent, which makes the process of management and decision-making more difficult and thereby affects the performance of the organization (Boyne, Meier 2009). That is why, according to the author, it seems appropriate to approach the problem of the use of the resource-based view in the management 
of public medical faciliites and its impact on the efficiency achieved by the organization.

The resource approach has an established position in strategic management theory but it does not give a lot of space in the area of strategic management of public organizations. This is due to the fact that it focuses strictly on resources that "feed" the system, which works basically the same in both public and private organizations. On the other hand, public management focuses mainly on the results the organization achieves and they are fundamentally different for the public and private sector (Klein, McGahan, Mahoney, Pitelis 2011). It is, however, difficult to agree with this approach as it brings down the whole RBV only to the analysis of the resources, excluding the most important issue which is that resources recognized as strategic can effect an improved performance of public organizations. Previous research on a public resource concept amongst public organizations was related mostly to the possible use of a specific resource in the organization, a priori assuming that the organization adopts the philosophy of the resource approach. A review of the conducted research is to be found in the next section of the article.

\section{Resource-based view in management of public organizations - a review of the literature}

The following part of the article presents the results of literature review provided for publications focusing on the use of the resource-based view in the management of public organizations. The overview of literature was carried out between June and September 2014, searching the following databases: EBSCO, Emerald Management Plus, Science Direct. The author is well aware of the fact that the literature review presented below certainly is not complete, nor it is comprehensive, nevertheless it provides a general overview of the researchers' approach to the possibility of implementing the resource-based view in the management of public organizations.

The conducted research has shown that the resource-based view is not particularly valued in the management of public organizations, while research examining the relationship between organization and resource-based view focuses on the potential of a specific resource to be used as strategic in achieving a sustainable competitive advantage, and at the same time improve organizational performance. Similarly, as indicated by the theory of resource-based approach, the primary focus was on intangible resources of the organization as those which have, in a way, the VRIO framework already built into them (Szymaniec 2012). 
As a whole, the resource-based view, as a key resource for the strategic management of public organizations, has been most widely appreciated in the work of J.M. Bryson, F. Ackermann, C. Eden (2007), where, along with case study, proposed was the use the so-called mapping as a tool for creating public organization's strategy. Under the proposed method, managers would be able to come up with the kind of map combining distinctive competencies of the organization with its aspirations, objectives and expectations of stakeholders, and on this basis create an organizational strategy, thus making it more efficient.

Direct indication of the resource-based view as an appropriate strategy for public organizations in a turbulent environment can also be found in the work of B. Butler (2009), where - with the help of focus groups - the possibility of implementing RBV in the management of public organizations in a dynamic environment was examined, and the identification of the resources and competencies necessary to cope with the environmental dynamics and uncertainty was made. The key organizational resources and competencies in the turbulent environment are:

- organizational culture focused on providing the highest quality of service,

- knowledge and its exchange within the organization,

- involvement of managers in the improvement of the organization,

- ability of organizational learning.

Knowledge as a strategic resource can also be found in the works of: D. Chan (2006), A. Goel, G. Rana, R. Rastogi (2010), G. Harvey, Ch. Skelcher, E. Spencer, P. Jas, K. Walshe (2010) oraz M.S. Sandhu, K.K. Jain, J.I. Kalthom bte Ahmad (2011).

In his research based on a survey questionnaire sent to employees of public libraries, D.Kan strived to identify resources and competences that enable public organizations to achieve above-average results. The results of the research, being most crucial second to knowledge, indicated the following resources and competences: communication skills, interpersonal skills, analytical skills, technical skills, organizational and planning skills, creativity, innovation, leadership (appearing also in the work of A. Gurtoo (2009)), responsibility and adaptability. If an organization does not obtain satisfactory results, it should introduce a refinement plan aiming to improvement the indicated resources and competences among their employees.

A. Goel, G. Rana, R. Rastogi (2010) pointed out that knowledge and appropriate management positively influence the organizational, managerial and financial aspects of the organization's performance, thus allowing it to achieve sustainable competitive advantage. An organization of above-average knowledge is able to 
create new combinations of traditional resources which is also beneficial with regard to achieving higher efficiency.

G. Harvey, Ch. Skelcher, E. Spencer, P. Jas, K. Walshe (2010), developed, based on the literature review, a model where the primary premise was the assumption that the development of absorptive capacity of knowledge within the public organization positively translates into the results achieved by this organization. It is through the absorptive capacity of knowledge that one should understand the process of acquiring, assimilating and implementing knowledge. This capacity is particularly important for public organizations due to the fact that they exist solely to meet the expectations and needs of their stakeholders, and in order to do it effectively, they must therefore be knowledgeable about their needs and expected methods of their meeting.

M.S. Sandhu, K. K. Jain, J.I. Kalthom (2011) bte Ahmad, coming from the assumption that knowledge is a strategic resource for organizations, used a questionnaire addressed to the employees of public organizations, trying to identify the barriers of knowledge sharing within organizations, as well as possible actions to encourage this type of behavior. The results of the research showed that employees personally believe that knowledge sharing is conducive to improving the competitiveness of the organization. At the same time, they pointed to the lack of a proper knowledge-sharing strategy within organizations, or failure to be presented with such strategy by the management, as one of the barriers to successfully implement this process. An important role was also played by personal motives (selfishness) and other organizational barriers, such as lack of technological information conducive to the sharing of knowledge, lack of rewards and recognition, lack of time or, last but not least, lack of interpersonal skills. Identified initiatives to support knowledge sharing were as follows: management support, development of IT technology, and cooperation between offices.

A. Gurtoo (2009), in his work, strived to identify resources and competencies of public organizations in India prior to the introduction of reforms aimed at marketization of their business from the early 90's, and which enabled smoother transition through the process of changes and faster adaptation to the new reality, as well as maintaining a competitive advantage. Identified resources included: leadership, loyalty of employees and their experience, knowledge sharing, access to government information (due to the public nature of the organizations).

In addition to knowledge and the resources mentioned above, the research also included resources such as: human resources (Kamoche 1997, Carmeli 2004, 
Carmeli, Schaubroeck 2005, Ridder, Bruns, Spier 2005, Fabiyola, Manicka Vasugi, Murugadoss 2010, Sadatsafavi, Walewski 2013), intellectual capital (Herremands, Isaac 2004, Kong 2007) and reputation (Smith 2008, Kong, Farrell 2010).

$\mathrm{K}$. Kamoche (2007) points to the necessity of paying closer attention to the development of human resources in public organizations as an essential factor influencing their success. He pays particularly close attention to the fact that it is not possible to build a competitive advantage for the organization on the basis of human resources without the awareness and understanding of the potential that lies in them by the management. Only then will managers be able to create an effective human resources strategy, translating into success of the organization as a whole. A similar assumption can be found in the works of A. Carmeli (2004) and A. Carmeli, J. Schaubroeck (2005). Studies from 2004 confirmed that, in an uncertain environment, organizations with strategic human capital (defined as having employees who are educated, engaged in their work, and meeting the VRIO framework criteria) achieve better financial results. In 2005, this relationship was supplemented with the assumption that the impact of human capital on the results of the organizational performance will be the greater, the higher is the perceived value of human capital among the management. Apart from the awareness of managers, another crucial element for the development of human capital is the issue of creating a working environment conducive to building human capital based on the RBV concept (Sadatsafavi, Walewski 2013).

H.D. Ridder, H.J. Bruns, F. Spier (2005) focused in their work on the identification of key assumptions under the competences of RBV with regard to a successful implementation of changes within the organization. The analyses conducted did not point directly to the generally perceived human capital. The specific role has been attributed to the involvement of managers in the process of change and their competence in creating new rules for the organization. Commitment and values one stands for (in a way, work ethic) as special features of employees (human capital) which make it possible to achieve above-average results were identified also in the work of K. Fabiyola, SP Manicka Vasugi S. H. Murugadoss (2010).

From human capital, we move onto a broader category of intellectual capital as a key organizational resource. Intellectual capital is a combination of the three inseparable categories of resources: human capital, structural capital (organizational learning, knowledge, processes, IT systems, brands, patents, licenses, infrastructure, strategies and organizational culture) and, finally, relational capital (internal and external relations) (Kong 2007). These works 
emphasize the role of intellectual capital in building a competitive advantage by enabling organizations to develop unique abilities, relations and processes, resulting in the development of leadership skills and overall welfare of the organization (Herremands, Isaac 2004, Kong 2007).

The reputation of an organization is also considered a strategic resource in managing public organizations. Literature studies conducted by E. Kong and M. Farrell (2010) show that, in the case of non-profit organizations, reputation and image are key resources in building and managing good relations with stakeholders - they allow the organizations to gain stakeholders' support, including financial support (e.g. grants). The research also shows the relatively fragile nature of the reputation and image, highlighting the need for ongoing management of these resources and their improvement. The need for proper management of reputation and image can also be found in the work of A.D. Smith, who believes that reputation should be constantly built and maintained as an important element of the overall organizational strategy. Furthermore, the organization should also be prepared for the eventuality of its reputation becoming undermined by developing relevant plans of action.

\section{Conclusions}

Implementing the logic of the resource-based view in the management of public organizations in a turbulent environment seems to be the right strategy. With that being said, however, there are still no clear results confirming this assumption. Research so far conducted has focused on a particular resource as a medium of a competitive advantage. In the opinion of the author, instead of considering a particular resource to be the key (human capital, knowledge, leadership) to success in a dynamic environment, one should instead focus more on promoting the approach of the resource-based view in the organization as an effective strategy. This means that the organization would be forced to look at its own resources and competences, and - depending on the situation - combine those resources which could give it a competitive advantage. Therefore, the organization should be flexible (Krupski 2008).

In further research, the author intends to focus on verifying the relationship between strategic orientation of the organization (market-wise or resource-wise) and organizational efficiency. The author will also try to find answers to the question whether basing the strategy of public organizations on the resourcebased view will help them achieve success in a turbulent environment. 


\section{Summary}

Resource-based view in strategic management of public organizations - a review of the literature

The resourced-based view has been widely used and appreciated in strategic management of private organizations. It is not, however, particularly popular in public management, although, as pointed out by the literature, it may be the solution to environmental turbulences that public organizations also have to face. This article focuses on presenting a review of to-date research relating to the use of resource-based view in the management of public organizations.

Keywards: $\quad$ resource based view $(R B V)$, public management, public organisation.

\section{Streszczenie}

Podejście zasobowe w zarządzaniu strategicznym organizacją publiczną - przegląd literatury

Podejście zasobowe ma ugruntowaną pozycje w zarządzaniu strategicznym organizacją publiczną. Niewiele miejsca poświęca się mu jednak w zarządzaniu publicznym, choć jak wskazuje literatura może być ono receptą na turbulencje otoczenia z która muszą się mierzyć także organizacje publiczne. Niniejszy artykuł skupia się na przeglądzie dotychczasowych badań z zakresu zastosowania podejścia zasobowego w zarządzaniu organizacją publiczną.

\section{Stowa}

kluczowe: podejście zasobowe, zarządzanie publiczne, organizacja publiczna.

\section{References}

1. Barney J., Clark D. (2007), Resource-Based Theory. Creating and Sustaining Competitive Advantage, Oxford University Press, New York.

2. Boyne G., Meier K. (2009), Environmental turbulence, organizational stability, and public service performance, "Administration \& Society", Vol. $40 \mathrm{Nr} 8$.

3. Bratnicki M., Ząbkowska B. (2007), Ponad planowanie strategiczne: w kierunku dialektyki i przedsiębiorczego uczenia sie [w:] Krupski R. (red.), Planowanie strategiczne w warunkach niepewności, „Prace Naukowe Wałbrzyskiej Wyższej Szkoły Zarządzania i Przedsiębiorczości", Wałbrzych. 
4. Bryson J.M., Ackermann F., Eden C. (2007), Putting the Resource-Based View of Strategy and Distinctive Competencies to Work in Public Organizations, "Public Administration Review", July | August.

5. Butler B. (2009), Successful Performance via Development and Use of Dynamic Capabilities, "The Business Renaissance Quarterly", Vol. 4 (3).

6. Carmeli A., Schaubroeck J. (2005), How Leveraging Human Resource Capital With Its Competitive Distinctiveness Enhances The Performance Of Commercial And Public Organizations, "Human Resource Management", Vol. 44 No. 4.

7. Carmeli A. (2004), Strategic human capital and the performance of public sector organizations, "Skandinavian Journal of Management", Vol. 20.

8. Chan D. (2006), Core Competencies And Performance Management In Canadian Public Libraries, "Library Management", Vol. 27 No. 3.

9. Dreyer B., Grønhaug K. (2004), Uncertainty, flexibility, and sustained competitive advantage, "Journal of Business Research", Vol. 57.

10. Fabiyola K., Manicka Vasugi S.P., Murugadoss S. (2010), An Empirical Study On Employee Core Competencies. A Proven Tool For An Organization's Success, "Interdisciplinary Journal Of Contemporary Research In Business", Vol. 2 No. 8.

11. Frączkiwicz-Wronka A., Szymaniec K. (2013), Zastosowanie koncepcji $R B V$ do pragmatyki funkcjonowania szpitali publicznych, "Organizacja i Kierowanie" nr 5.

12. Fredericks E. (2005), Infusing flexibility into business-to-business firms: A contingency theory and resource-based view perspective and practical implications, "Industrial Marketing Management".

13. Goel A., Rana G., Rastogi R. (2010), Knowledge Management as a Process to Develop Sustainable Competitive Advantage, "South Asian Journal of Management", Vol. 17 No. 3.

14. Grant R. (2003), Strategic planning in a turbulent environment: Evidence from the oil majors, "Strategic Management Journal", Vol. 24.

15. Gurtoo A. (2009), Adaptation Of Indian Public Sector To Market-Based Economic Reforms. A Resource-Based Perspective, "International Journal of Public Sector Management", Vol. 22 No. 6.

16. Harvey G., Skelcher Ch., Spencer E., Jas P., Walshe K. (2010), Absorptive capacity in a non-market environment. A knowledge-based approach to analysing the performance of sector organizations, "Public Management Review", Vol. 12 Issue 1.

17. Herremans I.M., Isaac R.G. (2004), Leading the strategic development of intellectual capital, "The Leadership \& Organization Development Journal", Vol. 25 No. 2.

18. Kamoche K. (2007), Competence-creation in the African public sector, "International Journal of Public Sector Management", Vol. 10 Iss: 4.

19. Klein P., McGahan A., Mahoney J., Pitelis Ch. (2011), Resources, Capabilities, 
and Routines in Public Organization, Working Papers, University of Illinois, College of Business, www.business.illinois.edu/Working_Papers. (data dostępu: 10 listopada 2013).

20. Kong E., Farrell M. (2010), The role of image and reputation as intangible resources in non-profit organisations: a relationship management perspective, ICICKM 2010: 7th International Conference on intellectual Capital, Knowledge Management and Organisational Learning, 11-12 Nov 2010, Hong Kong, China.

21. Kong E. (2007), The strategic importance of intellectual capital in the non-profit sector, "Journal of Intellectual Capital", Vol. 8 No. 4.

22. Koźmiński A. (2005), Zarządzanie w warunkach niepewności. Podręcznik dla zaawansowanych, Wydawnictwo Naukowe PWN, Warszawa.

23. Krupski R. (2012), Badanie zasobów przedsiębiorstw z perspektywy strategicznej, "Organizacja i Kierowanie”, nr 1A (149).

24. Krupski R. (2011), Orientacja zasobowa w badaniach empirycznych. Identyfikacja horyzontu planowania rynkowych i zasobowych wielkości planistycznych, Wałbrzyska Wyższa Szkoła Zarządzania i Przedsiębiorczości, Wałbrzych.

25. Krupski R. (red.) (2008), Elastyczność organizacji, Uniwersytet Ekonomiczny we Wrocławiu, Wrocław.

26. Lev S., Fiegenbaum A., Shoham A. (2008), Managing absorptive capacity stocks to improve performance: Empirical evidence from the turbulent environment of Israeli hospitals, "Journal of Business Research", Vol. 61.

27. Perrott B.E. (2008), Managing strategy in turbulent environments, "Journal of General Management", Vol. 33 No. 3.

28. Pettus M.L., Kor Y.Y., Mahoney J.T. (2007), A Theory of Change in Turbulent Environments: The Sequencing of Dynamic Capabilities Following Industry Deregulation.

29. www.business.uiuc.edu/Working_Papers/papers/07-0100.pdf (data dostępu 13 listopada 2013).

30. Ridder H-D., Bruns H-J., Spier F. (2005), Analysis of public management change Processes: the case of local Government accounting reforms in Germany, "Public Administration".

31. Sadatsafavi H., Walewski J. (2013), Corporate Sustainability: The Environmental Design and Human Resource Management Interface in Healthcare Settings, "Health Environments Research \& Design Journal", Vol. 6(2).

32. Sandhu M.S., Jain K.K., Kalthom bte Ahmad J.I. (2011), Knowledge Sharing Among Public Sector Employees: Evidence From Malaysia, "International Journal of Public Sector Management", Vol. 24 No. 3.

33. Smith A.D. (2008), Resource Based View of the Firm: Measures of Reputation Among Health Service-Sector Businesses, "Health Marketing Quarterly", Vol. 25(4). 
34. Szymaniec-Mlicka K. (2014), Charakterystyka otoczenia organizacji publicznych, Artykuł po otrzymaniu pozytywnych recenzji oczekuje na publikacje w Zeszytach Naukowych Politechniki Śląskiej.

35. Szymaniec K. (2012), Wykorzystanie podejścia zasobowego (RBV) do kształtowania relacji z interesariuszami i zarzadzania organizacja publiczna, [w:] Frączkiewicz-Wronka (red.) (2012), Wykorzystanie analizy interesariuszy w zarzadzaniu organizacja zdrowotna, Wyd. Sląsk, Katowice.

36. Waterhouse M. (1992), Managing effectively in turbulent environments, "Journal of strategic Change", Vol. 1. 